\title{
Author Correction: Fully Printed Wearable Vital Sensor for Human Pulse Rate Monitoring using Ferroelectric Polymer
}

Tomohito Sekine ${ }^{1}$, Ryo Sugano $^{1}$, Tomoya Tashiro ${ }^{1}$, Jun Sato ${ }^{1}$, Yasunori Takeda ${ }^{1}$, Hiroyuki Matsui ${ }^{1}$, Daisuke Kumaki ${ }^{1}$, Fabrice Domingues Dos Santos ${ }^{2}$, Atsushi Miyabo ${ }^{3}$ \& Shizuo Tokito ${ }^{1}$ Correction to: Scientific Reports https://doi.org/10.1038/s41598-018-22746-3, published online 13 March 2018

The version of this Article previously published contained lower resolution images for Figures 1, 2, 3, 4, 5 and 6. This has now been corrected in the PDF and HTML versions of the paper.

(i) Open Access This article is licensed under a Creative Commons Attribution 4.0 International (c) License, which permits use, sharing, adaptation, distribution and reproduction in any medium or format, as long as you give appropriate credit to the original author(s) and the source, provide a link to the Creative Commons license, and indicate if changes were made. The images or other third party material in this article are included in the article's Creative Commons license, unless indicated otherwise in a credit line to the material. If material is not included in the article's Creative Commons license and your intended use is not permitted by statutory regulation or exceeds the permitted use, you will need to obtain permission directly from the copyright holder. To view a copy of this license, visit http://creativecommons.org/licenses/by/4.0/.

(C) The Author(s) 2018 